\title{
O demônio familiar, de José de Alencar, no Teatro D. Maria II (Lisboa, 1860)
}

\author{
Silvia Cristina Martins de Souza ${ }^{1^{*}}$ \\ ${ }^{1}$ Universidade Estadual de Londrina, Londrina/PR - Brasil
}

\section{RESUMO}

Neste artigo são analisadas apresentaçôes de $O$ demônio familiar, de José de Alencar, realizadas no Teatro D. Maria II, em Lisboa, em 1860. O objetivo é mostrar que episódios como este podem ajudar na compreensão sobre as formas de apropriação da dramaturgia brasileira pela cena portuguesa e dos possíveis lugares que ela ocupou nos seus palcos, relativizando uma noçáo partilhada por alguns estudiosos segundo a qual não teria havido uma adoção do repertório teatral brasileiro pelas companhias portuguesas no século XIX.

Palavras-chave: José de Alencar; $O$ demônio familiar; Lisboa; 1860.

\section{The Family Demon, by José de Alencar, at the D. Maria II theater (Lisbon, 1860)}

\section{ABSTRACT}

This article analyzes performances of José de Alencar's The Family Demon at the D. Maria II Theater in 1860. The goal is to show that these performances can help our understanding of the ways the Portuguese theatrical scene appropriated Brazilian dramaturgy. The article shows the possible areas in which Brazilian dramaturgy influenced Portuguese theater, which challenges the notions of scholars who claim that the Portuguese theater companies in the 19th century did not appropriate Brazilian theatrical repertoire.

Keywords: José de Alencar; The Family Demon; Lisbon; 1860.

DOI: http://dx.doi.org/10.1590/2237-101X02204606

Artigo recebido em 3 de outubro de 2019 e aceito para publicação em 18 de maio de 2020.

* Professora da Universidade Estadual de Londrina / Centro de Letras e Ciências Humanas / Departamento de História, Londrina/PR - Brasil. Bolsista CNPq PQ-2. E-mail: smartins@uel.br. ORCID: https://orcid. org/0000-0002-8824-4477. 


\section{El Demonio Familiar, de José de Alencar, en el Teatro D. María II (Lisboa, 1860)}

\section{RESUMEN}

En este artículo son analizadas las presentaciones de El Demonio Familiar de José de Alencar, realizadas en el Teatro D. María II, en 1860. El objetivo es mostrar que episodios como estos pueden ayudar en la comprensión sobre las formas de apropiación de la dramaturgia brasileña por la escena portuguesa y de los posibles lugares que ella ocupó en sus escenarios, relativizando una noción compartida por algunos estudiosos según la cual no hubo una adopción del repertorio teatral brasileño por las compañías portuguesas en el siglo XIX.

Palabras clave: José de Alencar; El Demonio Familiar; Lisboa; 1860.

A noite de 24 de dezembro de 1860 foi de novidades para os lisbonenses e sobre ela Júlio César Machado nos legou algumas informaçôes no seu folhetim do jornal $A$ Revolução de Setembro, publicado no dia seguinte. De acordo com ele, durante muito tempo vigorara em Lisboa um "tolíssimo veto do poder eclesiástico" que proibia os teatros de funcionarem na véspera e no dia de Natal", o que transformou tais noites em momentos "de tristeza, de recolhimento e de sono" nas quais tudo o que se fazia era comer perus e broas e, à meia-noite, dirigir-se à igreja. Em 1860, com a suspenção de tal veto, a situação foi diferente e os lisbonenses puderam assistir a espetáculos no Teatro Circo Price e nos teatros de Sáo Carlos, Ginásio e D. Maria II. ${ }^{1}$

No Teatro Ginásio deu-se o espetáculo em benefício do ator Torquato; ${ }^{2}$ no de São Carlos representou-se a ópera $A$ filha do Regimento, de Donizetti; no Teatro Circo Price, Irma Monfroid dançou sobre um cavalo e atravessou arcos de flores, ${ }^{3}$ e no Teatro D. Maria II foi oferecida uma récita da qual constou o drama Judith e

um pequenino ato $O$ demônio familiar. Familiar ou não, é de um demônio que se trata - o que nos tira o direito de lhe exigirmos as virtudes de um anjo. É decerto fundado no seu fatal

\footnotetext{
${ }_{1}^{1}$ A Revolução de Setembro (PT), ano 21, n. 5.595, p. 2, 25 dez. 1860. Trata-se do decreto de 4 de outubro de 1869, que instituiu um novo Regulamento para Administração dos teatros portugueses. Na década de 1820, a viajante inglesa Marianne Baillie observou, de maneira semelhante a Júlio César Machado, que "Christmas does not appear to be kept with much hilarity in this country", o que nos faz crer que este veto vigorou por pelo menos quarenta anos (BAILLIE, 1824, p. 23-24). Os periódicos citados são acompanhados da sigla PT, quando se tratar de jornais portugueses, e com as iniciais da província em que foram editados, quando brasileiros.

${ }^{2}$ A Revolução de Setembro (PT), ano 21, n. 5.594, p. 3, 23 dez. 1860. Espetáculo em benefício era aquele em que parte da bilheteria era revertida para o beneficiado, após abatidas as despesas ordinárias do teatro.

${ }^{3}$ A Revolução de Setembro (PT), ano 21, n. 5.595, p. 3, 25 dez. 1860.
} 
direito, que o herói da açáo, rapazito esperto e audacioso, se obstina a levar de malícia em malícia as breves cenas da comédia. Ela não é um curso de moral, para dizer a verdade; mas a moral é uma coisa tão pesada e insípida, que se pode dispensar de vez em quando, sem fazer falta a ninguém. De mais a mais, a sra. Emília Adelaide no papel do rapazinho é tão graciosa, tão animada, tão caprichosamente esbelta e tâo sedutoramente traquina, que não há maneira de cuidar de outra coisa senão de olhar para ela e de a aplaudir. ${ }^{4}$

Para os que conhecem o teatro de José de Alencar, chama atenção no trecho acima reproduzido o título deste "pequenino ato", por ser o mesmo de uma de suas peças mais conhecidas e elogiadas tanto por seus contemporâneos quanto nos estudos posteriores dedicados à sua dramaturgia. No folhetim, todavia, não era mencionado o nome do autor dessa peça, nem tampouco o da tragédia Judith, embora a autoria desta última fosse conhecida dos lisbonenses que compareceram a outras récitas em que ela foi encenada ou leram o folhetim do dia 4 de dezembro d'A Revolução de Setembro que dizia tratar-se de uma livre traduçáo em prosa e verso do original do italiano Paolo Giacometti, especialmente encomendada pela empresa do D. Maria II a Mendes Leal. ${ }^{5}$ Além disto, Judith dispensava maiores apresentaçôes, porque já fora encenada em Lisboa no ano anterior, no original, pela atriz italiana Adelaide Ristori, com grande sucesso, tanto que, quando foi anunciada a estreia da tradução, a notícia se espalhou pela cidade alimentando um clima de expectativas a ponto de não haver "um camarote, não hav[er] um bilhete, não ha[ver] um lugar, há mais de um mês". ${ }^{6}$

Aos olhos de hoje causa estranhamento a ausência dos nomes dos dramaturgos nos anúncios de espetáculos teatrais, mas esta era uma prática comum no século XIX devido, em parte, à concepçáo de espetáculo entáo vigente, bastante diferente do que hoje chamamos de teatro. As récitas podiam ser compostas por três ou cinco peças diferentes "com vários atos, numa duração total que podia chegar a cinco horas" nas quais "era conveniente, e de alguma eficácia na recuperação da atenção do público, a utilização de um medium performativo diferente do da representação". A inserção de pequenas peças e números musicais nesses espetáculos tinha um caráter funcional, servindo para "separar as partes do programa, voltar a reunir a audiência e preparar emocionalmente para mais uma tranche" (GONÇALVES, 2012, p. 176). Eram, portanto, os espetáculos como um todo o que mais interessava e, por náo terem o estatuto de exceção, as peças complementares e os nomes de seus autores tendiam a neles desaparecer.

Essa ausência estava relacionada, também, ao reconhecimento tardio dos direitos de propriedade intelectual em Portugal. Foi com o decreto de 8 de julho de 1851 que surgiu a primeira lei definindo os direitos dos autores de "publicar ou de autorizar a publicação ou

\footnotetext{
${ }^{4}$ A Revolução de Setembro (PT), ano 21, n. 5.595, p. 2, 25 dez. 1860.

${ }^{5}$ A Revolução de Setembro (PT), ano 21, n. 5578, p. 1, 4 dez. 1860.

${ }^{6}$ O Occidente (PT), ano 29, n. 29, p. 239, 20 out. 1906.
} 
reprodução de uma obra", por tipografia, gravura "ou qualquer outro meio". 7 Esse reconhecimento legal não foi, porém, acompanhado da eliminação imediata de algumas práticas já consolidadas, como a ausência dos nomes dos autores nos anúncios das récitas, até porque ela muitas vezes servia para encobrir contrafaçôes e plágios.

Não consiste uma novidade afirmar que, nas últimas décadas do século XIX, José de Alencar fosse um literato conhecido no Brasil desde muito tempo, bem como em Portugal e alguns países europeus. No ano de 1866, o semanário Archivo Pittoresco publicou uma matéria que dizia ser ele "um dos ornamentos mais distintos da atual literatura do Brasil". ${ }^{8}$ Seu romance $O$ guarani teve duas publicaçóes na França, uma em 1886 e outra em 1899 (HEINEBERG, 2016, p. 194), uma na Alemanha, em 1872 (WIEBKE, 2016, p. 165), e outra na Itália, em 1871. Iracema já tinha uma tradução para o inglês antes de 1875 (BEZERRA, 2016, p. 186)'; em 1865, A viuvinha, Cinco minutos e Asas de um anjo tiveram duas ediçóes feitas em Paris por Garnier (GRANJA, 2013, p. 18), e Til foi publicado como folhetim no periódico português A República em 1871 (BORGES, 2013). Além disso, quando esteve em Lisboa em 1876, em busca de tratamento para a tuberculose que o acometia, sua passagem foi noticiada em jornais de maneira discreta, mas com "simpatia e admiraçâo", o que denota que ele conquistou a estima de parte da crítica lusitana. ${ }^{10}$

Alencar tinha consciência da existência de leitores estrangeiros de suas obras tanto que, ao comentar o insucesso de sua peça $O$ jesuita, na polêmica que travou com Joaquim Nabuco em 1875, ele disse: "Desde muito descobri que o meu público é mais brasileiro e até mais estrangeiro do que carioca" (COUTINHO, 1978, p. 201). Mas, se seus romances cruzaram fronteiras, sua dramaturgia parece não ter tido o mesmo destino ou, se teve, dele pouco se tem conhecimento nos dias de hoje.

Existe uma noção construída com base nas memórias do ator português Carlos Santos, que considera que, a despeito da proximidade linguística, das convivências e relaçóes travadas entre literatos portugueses e brasileiros, bem como da circulação de peças proporcionada pelas turnês teatrais, não ocorreu uma adoção da dramaturgia brasileira pelos repertórios das companhias portuguesas no século XIX (WERNECK, 2016, p. 25). Diante dela, encenaçôes como as d'O demônio familiar, no Teatro D. Maria II podem servir como porta de entrada privilegiada para lançar alguma luz sobre esse tema que ainda foi pouco explorado nos estudos sobre o teatro brasileiro oitocentista.

Tomando como objeto tais encenaçôes, procuraremos mostrar que essa noção tende a relegar ao esquecimento outras experiências que desnudam um quadro mais complexo sobre um rico momento do passado cultural luso-brasileiro. Esse exercício esbarrou em alguns obstáculos. O primeiro deles foi a identificação da autoria da peça, sobre a qual

\footnotetext{
7 Coleção Oficial da Legislação Portuguesa. Lisboa: Imprensa Nacional, 1852, p. 233.

${ }^{8}$ Archivo Pittoresco (PT), ano 9, n. 31, p. 244, 1866. O artigo é de Innocêncio Francisco da Silva.

${ }^{9}$ A primeira edição, contudo, só foi publicada em 1886.

${ }^{10}$ Diário da Manhã (PT), n. 364, p. 1, 20 set. 1876.
} 
fomos beneficiados pela leitura do trabalho de Izabel Gonçalves dedicado ao músico português Joaquim Casimiro Júnior. Nele, a autora apresenta um levantamento das composiçôes músico-teatrais deste músico no qual consta 1860 como ano de encenação da comédia $O$ demônio familiar, da qual Gonçalves localizou exemplares tanto da peça de Alencar, quanto das partituras de Casimiro Júnior, conservados nos acervos da Biblioteca Nacional de Portugal e do Teatro D. Maria II (GONÇALVES, 2012, p. 15). O segundo obstáculo foi a fragmentação e exiguidade das fontes. A mais detalhada delas é o folhetim de Júlio César Machado, anteriormente citado. Afora ele, tivemos acesso a alguns anúncios de espetáculos, todos também n’A Revolução de Setembro. Trata-se, sem dúvidas, de um conjunto documental rarefeito, mas, por não querermos abrir mão de explorar esse episódio em função do seu ineditismo, optamos por concentrar a investigação num campo de possibilidades historicamente determinadas. Desse movimento decorreu o uso de conjecturas, evidências paralelas e cruzamentos de informaçôes, tanto no decorrer da pesquisa quanto na elaboração do texto, como o leitor terá oportunidade de constatar (DAVIS, 1987).

Foi no século XIX que os folhetins surgiram na imprensa francesa. Se inicialmente a palavra folhetim esteve associada a um lugar específico do jornal - o seu rodapé -, com o tempo esse espaço foi ganhando autonomia em relação a outras seçóes e matérias, e alguns temas foram nele se enraizando, surgindo expressões tais como folhetins dramáticos, literários, variedades, musicais e romance-folhetim para denominá-los. O sucesso que o folhetim passou a desfrutar, a partir de entáo, o transformou num instrumento de projeção para novos escritores, de consagração para os já conhecidos, de ampliação de leitores e de aumento das receitas dos periódicos.

Introduzido em Portugal no final da década de 1830, lá, assim como na matriz do gênero, a temática teatral foi ocupando mais espaço à medida que o folhetim foi-se popularizando e fidelizando leitores, e dois autores nele se tornaram referenciais: Lopes de Mendonça e Júlio César Machado. ${ }^{11}$ Se foi n'A Revolução de Setembro, onde colaborou de 1846 a 1858, que Lopes de Mendonça fez nome como primeiro crítico dos principais acontecimentos teatrais, sociais e literários de Lisboa, foi nesse mesmo periódico que, ao sucedê-lo, Júlio César Machado se consagrou tornando-se tão ou mais popular que seu antecessor. Nesse periódico ele foi responsável pela série "Revista da Semana", que saiu todas as terças-feiras entre 1859 e 1881, na qual o teatro foi assunto privilegiado, embora muitas vezes não ocupasse toda a crônica ou nem a maior parte dos artigos. ${ }^{12}$

\footnotetext{
${ }^{11}$ Ver sobre o assunto Ferreira (2011) e Outeirinho (2013).

${ }^{12}$ Júlio César Machado também escreveu folhetins para o Diário de Notícias e foi revisor da Revista Universal Lisbonense.
} 
Essa preferência temática torna Júlio César Machado um dentre uma série de outros indivíduos que atuaram na imprensa e vivenciaram um fenômeno que tomou corpo a partir dos anos 1850: o da emergência do teatro como fenômeno global. De acordo com Christopher Balme, foi a partir dessa década que a natureza do teatro foi modificada no mundo inteiro e ele se transformou no meio de entretenimento coletivo popular mais bem-sucedido, fazendo com que as artes cênicas deixassem de ser uma forma cultural definida, praticada e experimentada de maneira predominantemente local para adquirir alcance global (BALME, 2016, p. 205). Em tal ambiente, a frequência dos folhetins dramáticos nos jornais atesta não apenas a popularidade do teatro, como também as estreitas ligaçôes entre ele e a imprensa, e a forma como se alimentaram e impulsionaram mutuamente.

Por ter como objetivo avaliar o espetáculo municiando o leitor que iria assisti-lo de informaçôes que lhe proporcionassem uma melhor compreensão da peça, assim como de permitir àquele que náo tivesse oportunidade de estar no teatro de imaginar-se como parte da audiência, o folhetim teatral foi pouco a pouco construindo uma narrativa própria: depois de um preâmbulo em que procurava chamar a atenção do leitor, o folhetinista apresentava um resumo da intriga, sintetizava as linhas gerais do enredo e analisava as performances dos atores. Com isto, pode-se dizer que além de informar sobre o espetáculo, o folhetim também cumpria a função de divulgá-lo.

Os folhetins de Júlio César Machado se destinavam em boa parte a comentar os espetáculos encenados nos teatros de primeira ordem de Lisboa ${ }^{13}$, e neles ele seguiu a fórmula anteriormente mencionada, com alteraçôes esporádicas. Foi o que ocorreu no folhetim do dia 25 de dezembro de 1860, no qual ele foi bastante econômico ao tratar de $O$ demônio familiar. Ao resumi-lo, Júlio César Machado se restringiu a dizer que era "de um demônio que se trata[va]" e que o protagonista não era "um curso de moral", mas sendo a moral uma coisa "pesada e insípida", podia ser de vez em quando "dispensada".

Quando encenada no Teatro Ginásio Dramático do Rio de Janeiro, em 1857, ao contrário, a peça de Alencar rendeu várias notícias e artigos em jornais e foi considerada um divisor de águas na dramaturgia brasileira por ser a primeira comédia realista escrita por um brasileiro, e um dos pontos que pesou para que ela fosse assim avaliada foi a moralidade da qual estava revestido o protagonista da peça (FARIA, 1989). Tamanha foi a repercussáo das encenaçôes no Rio, que não faltaram debates no Diário do Rio de Janeiro, Correio Mercantile A Marmota, nos quais se confrontaram diferentes interpretaçóes e avaliaçóes da peça, ainda que a maior parte delas fosse elogiosa (SOUZA, 2003).

Estamos diante, como se pode ver, de duas avaliaçôes distintas, mas que colocadas em diálogo podem nos levar a elaborar algumas consideraçóes interessantes. A primeira delas

\footnotetext{
${ }^{13}$ Teatro de primeira ordem era a denominação dada aos teatros subsidiados pelo governo português, isto é, o de D. Maria II e o de São Carlos, em Lisboa, e o de São João, no Porto. Os demais eram chamados teatros secundários. Ver Cymbron (1990, p. 104).
} 
diz respeito ao lugar que essa comédia ocupou na récita do D. Maria II e, ao denominá-la "pequenino ato", Júlio César Machado nos permite levantar algumas hipóteses.

A peça de José de Alencar é uma comédia em quatro atos, nove personagens, teve nove representaçóes consecutivas no Rio de Janeiro (um sucesso para a época!), e em todas as récitas foi a peça principal. Em Portugal, ela estreou num espetáculo em benefício dos atores Manuel Francisco Correa e Joaquim José da Silva Moreira, ao lado de duas outras peças, e a partir daí introduzida como complemento das récitas em que a peça principal foi a tragédia Judith. Isto significa dizer que ela passou por ajustamentos para acomodar-se a tais espetáculos e de um deles somos informados pelo anúncio do espetáculo de estreia, divulgado dois dias antes da estreia, que reproduzimos abaixo:

\section{Figura 1}

\section{ESPECTACULOS.}

\section{THEATRO DE D. MARIA II.-Quinta-feira, 20. -Judith - $-\mathrm{A} 10^{\circ}$ representação da comedia em 1 acto - 0 Demonio Familiar.}

Fonte: A Revolução de Setembro, ano 21, n. 5.589, p. 4, 18 dez. 1860

Hemeroteca Digital da Biblioteca Nacional de Portugal

Disponível em: http://purl.pt/14345

O demônio familiar que estreou em Lisboa ganhou o formato de um entreato, isto é, de uma cena em ato único adequada ao "espaço de tempo que decorre entre dois atos de uma peça, ou entre duas peças diferentes" (SOUSA BASTOS, 1908, p. 57). Não foi possível saber quem fez as alteraçôes ao texto adaptado mas, a levar-se em conta as informaçôes do ator, autor e empresário português Sousa Bastos, podemos dizer que se tratou de uma adaptação, nome que se dava ao trabalho de acomodar o enredo, os caracteres e os costumes de um texto teatral para o país em que a peça seria encenada, o que nos encaminha para o segundo ponto: o enredo e o protagonista (SOUSA BASTOS, 1908, p. 12).

É da escravidão que trata a comédia de Alencar, e dos males que, na sua visão, ela produzia à família e à sociedade brasileiras. Como Alencar construiu o enredo com base na estética realista, tornou-se necessário que ele se concentrasse na observação de um tema contemporâneo com o objetivo de analisá-lo e discuti-lo no palco para no desfecho endereçar uma mensagem ao espectador, seguindo os pressupostos do que se entendia por realismo naquele contexto.

O personagem referido no título da peça, o "demônio familiar", é Pedro, uma "cria da casa", expressão comum no Brasil Oitocentista que os espectadores fluminenses rapidamente podiam identificar. Ela era utilizada para nomear os jovens escravos nascidos no Brasil que 
exerciam um trabalho doméstico algumas vezes não muito bem definido. Da forma como concebido pelo dramaturgo, Pedro precisava ser revestido de algumas características que o tonassem digno de ser visto como um elemento desestabilizador da ordem doméstica. Por isto, ele é um personagem em que a malícia, o poder de observação, o cálculo e a capacidade de decodificação do mundo em proveito próprio são colocados em destaque (SOUZA, 2003, p. 99-102). Sáo eles que o levam, por exemplo, a roubar charutos a seu senhor ou a ser o mensageiro das cartas que a irmá deste recebe às escondidas de um pretendente. Sáo suas açôes, tal como Alencar procurou mostrar, que corrompiam os valores morais da sociedade e da família, açôes estas que não eram aleatórias, pois o motivo que movia Pedro era seu desejo de tornar-se cocheiro, o que o colocava em contradição com sua situação de escravizado, considerado sem vontade própria, e em oposição aos interesses do seu senhor.

A concepção da personagem foi engenhosa pois, ao imaginar Pedro como um escravo doméstico, Alencar permitiu que ele usufruísse uma relação mais intensa com o seu senhor, fruto da natureza do trabalho que exercia. E, ao reproduzir esse costume da sociedade brasileira, o dramaturgo deu visibilidade no palco a uma rede conhecida de obrigaçóes, expectativas e exigências implícitas nas posiçôes de domínio e submissão entre senhores e escravos. Dessa forma, e em função da sua capacidade de tramar e destramar fazendo com que todos os outros personagens se transformassem em marionetes movidos pelos fios que ele puxava, Pedro emergia como uma exceção à regra. Com isto, Alencar conduzia o espectador brasileiro a raciocinar a partir de códigos que lhe eram familiares e simultaneamente chamava atenção para a ameaça que significava o afrouxamento das relaçôes entre senhores e seus cativos, por relaxamento do controle e da disciplina (AZEVEDO, 2004, p. 12). No desfecho da peça, Pedro recebia a alforria como castigo imposto a um escravo insubmisso e despreparado para usufruir a liberdade, que passava a ser responsável por seus atos e entregue à própria sorte, por não contar com a proteçấo do seu ex-senhor para ampará-lo. ${ }^{14}$ Alencar apresentou, dessa forma, uma representação da escravidão como um mal, por transformar o senhor em escravo do seu escravo, e como um obstáculo à manutençáo dos valores familiares e sociais, fazendo com que sua peça emergisse como uma mensagem direcionada às elites escravistas (ALONSO, 2005). ${ }^{15}$

No folhetim de Júlio César Machado não é feita nenhuma alusão ao nome do protagonista (nem aos dos demais personagens) ou à sua condição social. São apenas destacadas

\footnotetext{
${ }^{14}$ Há algum tempo os historiadores vêm demonstrando que as relaçôes de sujeição e dependência construídas durante a escravidão não se extinguiam com a alforria e do liberto era esperado que mantivesse os "laços morais" que os ligavam ao ex-senhor vistos como indispensáveis para sua sobrevivência na nova condição. Ver sobre o assunto Chalhoub (1990).

${ }^{15}$ As ideias de Alencar sobre emancipação não passavam pelo apoio à abolição total e imediata. Ele foi um dos conservadores apelidados de "emperrados", que fez a defesa do status quo argumentando que o fim da escravidão traria a bancarrota econômica, a anarquia política e a convulsão social. Em função disso, ele não negava a emancipação, mas defendia que ela fosse fruto da deliberação de cada senhor, devendo ser tratada como uma questão de foro íntimo e sem qualquer intervenção do Estado.
} 
sua esperteza, audácia e malícia, que o folhetinista considerou pertinentes ao personagem. Atributos estes que, vale dizer, eram semelhantes à representação dos escravos que exerciam serviços domésticos em Portugal, embora o folhetinista não os mencionasse. Lá também os meninos e jovens cativos eram os mensageiros da casa, acompanhavam os donos quando saíam à rua, traziam e levavam recados e, em função dessa proximidade com os senhores, estavam a par dos jogos amorosos e assuntos íntimos que circulavam pelas casas dos seus amos (PIMENTEL, 2010). Tais jovens, nas palavras de D. Francisco Manuel de Melo, eram vistos como "diabos, ladinos e chocarreiros [que] por castanhas trazem e levam recados às moças e são delas favorecidos" (MELO, s/d, p. 176). O que Júlio César Machado priorizou na sua análise, contudo, foram os elementos de comicidade que aproximavam Pedro dos lacaios e criados espertos comuns "na comédia de Plauto, na velha Roma [...] na commedia dell'arte italiana e na comédia francesa a partir de Molière" (FARIA, 2003, p. 18), e de uma tradição dos entremezes portugueses (CRUZ, 2006).

De fato, essa semelhança existe e foi percebida no Brasil por Paula Brito e Machado de Assis quando da estreia da peça no Rio. Machado definiu o protagonista como "o Fígaro brasileiro, menos as intençōes filosóficas e os vestígios políticos do outro", deste guardando "o caráter do intrigante doméstico, mola real da açâo", mas deixando claro que eram a escravidão e seus males o centro da comédia. ${ }^{16}$ Paula Brito, anos antes de Machado, disse que "Pedro, o demônio familiar, é o Fígaro, como dissemos, porque mudadas as condiçôes, mudada a cor, mudadas as profissóes, os trajes, etc. Fígaro é Pedro, e Pedro é Fígaro". ${ }^{17}$

Semelhanças à parte, a questão que aqui se impõe é buscar entender por que Júlio César Machado "dispensou" falar sobre a moralidade da peça e preferiu omitir-se sobre a condição social do protagonista no seu folhetim. $\mathrm{O}$ fato de não termos tido acesso ao texto adaptado para a representação (se é que ele existe!) é um complicador, o que, todavia, não nos impede de formular algumas hipóteses. Uma delas é que talvez seu silenciamento tivesse a ver com o fato de a escravidão ser um tema também sensível em Portugal nos anos 1860, embora não com a mesma intensidade que no Brasil. Em Portugal, a questão da abolição era de ultramar e dizia respeito ao império português e suas colônias, diferentemente do que acontecia no Brasil, onde era uma "bomba prestes a explodir dentro de casa" (apud ALONSO, 2005, p. 31).

A questão da abolição nos domínios portugueses arrastou-se por quase quarenta anos desde o decreto elaborado pelo liberal Sá Bandeira, em 1836, que proibiu a exportação de escravos para as colônias pelo mar (no caso de Angola, pelo continente), até o decreto de 1875, que estabeleceu a liberdade dos escravos. Durante esse período, uma série de projetos visando à abolição foram apresentados à Câmara dos Pares, mas suas discussóes recorrentemente adiadas (MARQUES, 2006).

\footnotetext{
${ }^{16}$ Diário do Rio de Janeiro (RJ), ano 46, n. 56, p. 2, 6 mar. 1866. Tal semelhança foi analisada detalhadamente por Décio de Almeida Prado (1974) e João Roberto Faria (2003).

${ }^{17}$ A Marmota (RJ), n. 898, p. 1, 10 nov. 1857. Grifo no original
} 
Entre poucos avanços e muitos recuos, a política da abolição no império português foi tratada a "conta gotas", na expressão de João Pedro Marques. A maior parte dos projetos foi encaminhada à Câmara dos Pares na década de 1840, momento que foi mais propício para debater medidas legislativas dessa natureza que só seriam aprovadas na década seguinte (MARQUES, 2006, p. 679). A partir da entrada do Cabralismo, a situação mudou de rumo e a estratégia adotada pelos abolicionistas foi lenta e gradualista para desarmar os adeptos do escravismo, convencer políticos, não alimentar a oposição dos interesses dos proprietários coloniais, concretizar o sonho de construção de novos Brasis, para os quais a escravidão era essencial, e para contemplar as expectativas da consciência de um país que se queria progressista. À parte isso, contou o fato de que não se tinha um exemplo de experiência de emancipaçáo no mundo escravista capaz de tranquilizar os espíritos mais apreensivos. O que havia, ao contrário, era a memória viva e emblemática do Haiti a alimentar temores em relação às revoltas de escravos, e a da Guerra de Secessão nos Estados Unidos, expondo as fraturas das elites (ALONSO, 2005, p. 31).

Nos anos 1850, as medidas legislativas mais importantes aprovadas foram o decreto de

14 de Dezembro de 1854, que obrigava a registrar todos os escravos existentes e que impunha a libertação dos que fossem possuídos pelo Estado e a daqueles que, daí em diante, fossem importados por terra; a lei de 12 de Julho de 1856, que introduzia a liberdade do ventre; e o decreto de 29 de Abril de 1858, que estabelecia um prazo máximo de vinte anos para o fim da escravidão em todo o território sob administração portuguesa (MARQUES, 2006, p. 680).

Esses decretos e lei preconizavam o que já havia sido aprovado no início do século e a única novidade apresentada foi o estabelecimento de um prazo bastante dilatado para o fim da escravidão. No ano de 1860, portanto, o assunto escravidão alimentava insatisfação entre liberais que se viam resignados a aceitar o que era politicamente possível de ser feito e a ver o assunto girar numa espécie de ponto morto na política. Talvez estes tenham sido alguns dos motivos que levaram Júlio Cesar Machado a evitar um assunto delicado, e ter preferido sublinhar na peça o que nela havia de comicidade, por ser esta bem acolhida pelas plateias portuguesas desde o século XVIII, o que parece ficar reforçado nos seus elogios à performance da atriz Emília Adelaide no papel de Pedro, que no Rio foi interpretado pelo ator Martins (FARIA, 2003, p. 36).

Em data não determinada no reinado de D. Maria I, as mulheres foram proibidas de representar, sendo os papéis femininos atribuídos a homens. ${ }^{18}$ Ao longo do século XIX, porém, as mulheres voltaram a surgir nos palcos, algumas delas atingiram status de atrizes famosas

\footnotetext{
${ }^{18}$ De acordo com Maria Emília Costa, não se sabe se a proibição de as mulheres pisarem nos palcos, bastidores e camarins do teatro foi definida por decreto ou se limitou a uma proibição verbal da rainha. Certo é que, segundo ela, "as mulheres, efetivamente, nesses anos sombrios, não tinham autorização para representar ou se aproximar dos lugares reservados aos atores" (COSTA, 2014, p. 18).
} 
e, em alguns casos, inverteram-se os papéis e mulheres passaram a interpretar papéis masculinos. De acordo com Sousa Bastos, adotou-se a palavra francesa travestis para

Indicar os papeis masculinos desempenhados por mulheres, ou os papeis femininos interpretados por homens. No primeiro caso, acontece que um ator tendo de apresentar em cena um adolescente, quase uma criança, distribui esse papel a uma mulher para the dar mais graça e naturalidade. Muitas vezes também se distribui a uma mulher um papel de apaixonado, que tem cenas provocadoras, para salvar a situação em frente do público, as quais podiam ser perigosas e excitar protestos. Também algumas atrizes se mostram táo espertas, vivas e desembaraçadas com fatos de homem, táo desejosas de fazer papeis masculinos, aos quais o seu talento e desenvoltura se prestam perfeitamente, que os autores, cedendo a tal fantasia, escrevem para elas papeis travestis que muitas vezes são representados na perfeição (SOUSA BASTOS, 1908, p. 108).

Emília das Neves, por exemplo, fez muito sucesso no papel do protagonista na comédia As primeiras proezas de Richelieu. Emília Adelaide da mesma forma notabilizou-se no do Marquês de Penha Flor, e a escolha do seu nome para o papel de Pedro deve ter se baseado na sua já comprovada habilidade para interpretar papéis travestis. No seu folhetim, Júlio César Machado sublinhou que sua performance foi tão graciosa e "sedutoramente traquina", que não havia "maneira de cuidar de outra coisa senáo olhar para ela e de a aplaudir", o que o eximia de discutir a moralidade da peça que ele reconhecia existir, embora considerasse discutível, argumentando que por ser a moral uma coisa "pesada e insípida", podia ser por vezes dispensada que não faria "falta a ninguém".

Por se tratar de ser um entreato, é preciso pensar também no lugar que a comédia de Alencar ocupou nas récitas do D. Maria II. Nos teatros oitocentistas, cabia aos diretores de cena o papel de intermediários entre autores e público, adequando as peças a seu gosto (UM DOS SEUS ADMIRADORES, 1873, p. 187). Desde 1853, quando Pedro Pimentel de Menezes de Brito do Rio foi indicado comissário régio dos teatros de primeira ordem de Lisboa, ${ }^{19}$ o ensaiador do D. Maria II foi Luiz da Costa Pereira. Chamavam-lhe "o doutor", pois era formado em Matemática, além de ser também ator e tradutor teatral (SOUSA BASTOS, 1898, p. 304). Júlio César Machado dizia dele que conseguia reunir a "lucidez dos matemáticos" à "graça chistosa e cáustica" e que por esse motivo foi um dos mais competentes diretores de cena do seu tempo (GONÇALVES, 2012, p. 102-103). Se associarmos essa tendência de Costa Pereira para a graça "chistosa", o gosto das plateias lisboetas pela comicidade e a interpretação "sedutoramente traquina" de Emília Adelaide, podemos sugerir que eles convergiram para um mesmo ponto, embora movidos por motivos diferentes: prover aquele "pequenino ato" da leveza e graça esperadas dos entreatos, retirando do original o que ele continha de polêmico.

${ }^{19} \mathrm{O}$ comissário régio era o gestor público dos teatros. 
As interpretaçóes que exploravam os aspectos risíveis desse personagem alencariano também aconteceram no Brasil, não apenas nos anos 1850, quando estreou, mas sobretudo na década de 1880, em que a questão da abolição começou a encontrar adeptos em diferentes setores da sociedade, acirrando a campanha abolicionista. Nesse período, tornou-se um atrativo das empresas teatrais a presença de crianças-prodígio nos elencos. Foi nesse novo ambiente que $O$ demônio familiar foi encenado pelas meninas Gemma Cuniberti, no teatro São Luiz ${ }^{20}$, e Julieta dos Santos, no Recreio Dramático ${ }^{21}$, quando ambas contavam dez anos. Gemma e Julieta se notabilizaram por suas interpretaçóes repletas de gestos, inflexôes e maneiras traquinas para reproduzir "o pequeno demônio azevinhado", a ponto de as duas empresas alimentarem uma concorrência entre as jovens atrizes para atrair bilheteria ${ }^{22}$.

Nesse sentido, o que mais surpreende em relação aos intérpretes de Pedro é a ausência de quaisquer referências à caracterização dos atores e atrizes em relação à cor do personagem, tanto em Portugal quanto no Brasil, salvo essa breve mençáo ao "demônio azevinhado", embora todos os que o interpretaram fossem brancos.

A presença de personagens negros em peças portuguesas remonta ao século XVI e no Setecentos já se tinha "um preto" nos entremezes como personagem recorrente (CRUZ, 2006, p. 18). Neles, tais personagens eram invariavelmente associados ao riso, à ridicularizaçáa, ao grotesco e à infantilização. ${ }^{23}$ Alguns atores brancos se especializaram na interpretação desses personagens em Portugal e dentre eles João Maria Ferreira foi um dos mais exitosos (SOUSA BASTOS, 1898, p. 171). Consta que foi na Revista de 1858 (OLIVEIRA, 1859) que ele se celebrizou ao protagonizar um negro escravizado que ao lado de um zelador da Câmara cantava um couplet composto por Joaquim Casimiro Júnior, que ficou conhecido pelo nome "pleto ribola", cujos versos diziam:

Pleto já não ser cativo!

Pleto ribola!

Por um decreto ficar livre!

Na noble Angola.

Pleto já stá cidadão

Pleto ribola!

Pleto já ter alforria

Na noble Angola!

\footnotetext{
${ }^{20}$ Revista Illustrada (RJ), ano 8, n. 3, p. 3, 16 jun. 1883.

${ }^{21}$ Diário do Brasil (RJ), ano 3, n. 164, p. 4, 18 set. 1883.

${ }^{22}$ Gazetinha (RJ), ano 1, n. 144, p. 2, 28 jun. 1882.

${ }^{23}$ Essa caracterização não esteve restrita ao teatro português sendo recorrente em vários palcos europeus e americanos. Para o caso brasileiro podemos dizer que a necessidade de pintar os rostos para a representação de papéis que exigissem atores negros em cena deve ter sido mais comum do que a documentação registra. Para uma análise aprofundada desse tema, ver Abreu (2017).
} 
(Estribilho)

Os Blanco ser esclavo oiê

Calega a saca dos café

Os Blanco ser esclavo

Oiê, oiê, oiê

(CASTILHO, 1862, p. 1).

Os versos desse couplet remetem ao decreto de 29 de abril de 1858, o qual estabelecia um prazo máximo de vinte anos para o fim da escravidão em todo o território português. Nele, o estatuto definido para os libertos permitiu abolir a escravidão sem que o fizesse substancialmente, pois estes passaram a ser tutelados por uma Junta especialmente designada para isso e obrigados a trabalhar para seus antigos senhores por um período de sete a dez anos.

As revistas de ano, como se sabe, tinham como centro a revisão e o comentário de acontecimentos significativos do ano anterior por meio do exacerbamento do ridículo, do burlesco e da sátira. Diante disso, entende-se o sentido crítico contido nesses versos, pois eles saíam da boca de um liberto iludido com uma liberdade da qual só iria usufruir tardiamente e com sua expectativa de uma suposta inversão de papéis que dela poderia decorrer. ${ }^{24} \mathrm{Visto}$ desse ângulo, constata-se que as características risíveis do protagonista da peça adaptada do original de Alencar estavam em sintonia com a forma esperada com que os personagens negros fossem retratados nos palcos lusitanos.

A música n'O demônio familiar representado no D. Maria II é outro elemento importante. Nem no texto de Alencar, nem nos folhetins que trataram das encenaçóes no Rio de Janeiro existem referências à presença da música como parte estruturante da trama ou da encenação. A única menção a ela aparece num breve momento em que Pedro cantarola um trecho da ária La Calunnia, d'O barbeiro de Sevilha:

PEDRO - Oh! Pedro sabe como há de arranjar este negócio. Nhanhã não se lembra, no teatro lírico, uma peça que representa e que tem homem chamado Sr. Fígaro, que canta assim:

Tra-la-la-la-la-la-la-la-tra!

Sono un barbiere di qualità!

Fare la barba per carità! ...

CARLOTINHA (rindo-se) - Ah! O Barbeiro de Sevilha!

PEDRO - É isso mesmo. Esse barbeiro, Sr. Fígaro, homem fino mesmo, faz tanta coisa que

\footnotetext{
${ }^{24}$ A expressão "pleto ribola" se popularizou a ponto de constar, por exemplo, da revista de ano Viagem à roda da Parvonia, de Gil Vaz, pseudônimo coletivo de Guerra Junqueiro e Guilherme de Azevedo (s/d, p. 60), representada no Teatro Ginásio de Lisboa em 1879, e num artigo do periódico Pontos nos is (13 ago. 1886, p. 118).
} 
arranja casamento de sinhá Rosinha com nhonhô Lindório. E velho doutor fica chupando no dedo, como aquele frade D. Basílio!

CARLOTINHA - Que queres tu dizer com isto?

PEDRO - Pedro tem manha muita, mais que Sr. Fígaro! Há de arranjar casamento de Sr. moço Eduardo com sinhá Henriqueta. Nhanhã não sabe aquela ária que canta sujeito que fala grosso? (Cantando) "La calunnia” (ALENCAR, 1858, p. 59-60).

No original de Alencar, a música aparece como mais um componente de reforço das características do protagonista, para as quais a ária La Calunnia foi uma escolha bastante feliz. Para a encenação portuguesa foram compostos três números musicais especialmente escritos por Casimiro Júnior para serem interpretados por um violino e duas violas no próprio palco, acompanhados por uma parte vocal (GONÇALVES, 2012, p. 474). De acordo com Isabel Gonçalves, na partitura que consta do acevo da Biblioteca Nacional de Portugal, o compositor anexou o termo vaudeville à palavra comédia (GONÇALVES, 2012, p. 143). ${ }^{25}$ Ao transformá-la numa comédia-vaudeville, Casimiro Júnior pôde inserir nela quantos números musicais achou convenientes, tal como era de praxe nesse gênero de teatro musicado, contemplando o gosto crescente de um público que desde o aparecimento das revistas passou a ter em alta conta a presença da música nas produçóes teatrais (FILIPE, 2012, p. 63).

É conhecida a posição de Alencar em relação aos diferentes gêneros de teatro musicado. Seu pouco apreço por eles advinha do fato de considerá-los desprovidos de valor artístico e voltados unicamente para o divertimento das plateias, sem contar que por serem formas teatrais importadas da França eram por ele (e outros homens de letras) reputados obstáculos à criação de uma dramaturgia nacional. Diante disso, transformar uma peça que ele escrevera com a intenção de ser uma comédia realista em uma comédia-vaudeville certamente lhe teria provocado irritação e levado a manifestar-se, caso tivesse tido conhecimento disto, assunto que abordaremos no momento oportuno. Por ora, gostaríamos de mencionar que $O$ demônio familiar teve seis apresentaçóes em Portugal, a primeira delas no dia 20 de dezembro a que compareceram "El-rei o sr. D. Pedro V, sua majestade o sr. D. Fernando e os srs. Infantes" (UM DOS SEUS ADMIRADORES, 1873, p. 218); a segunda ocorreu no dia 23 de dezembro, no espetáculo em benefício dos atores Correa e Moreira, e as demais nos dias 24, 27, 29 e 30 de dezembro.

Do benefício constaram, além de $O$ demônio familiar, as peças Dai aos pobres, cuja autoria não conseguimos identificar, e o Morgado de Fafe, de Camilo Castelo Branco. A escolha dessas peças foi feita num contexto de mudanças que já vinham ocorrendo desde que o decreto de 14 de outubro de 1859 proibiu os atores do teatro D. Maria II de escolherem

\footnotetext{
${ }^{25}$ De acordo com Isabel Gonçalves, a partitura autografada da música encontra-se na Biblioteca Nacional de Portugal (cota M.M. 44//8 e no TNDMII., cota X. 06) e uma cópia manuscrita com as partes vocal e instrumental na Biblioteca Arquivo do Teatro Nacional D. Maria II, (X. 06).
} 
para seus benefícios peças que já não fizessem parte do repertório do teatro. Tais medidas objetivavam diminuir os custos com novas montagens que demandassem investimentos em cenários, figurinos e novos contratos de direitos autorais (COSTA, 2014, p. 51). Como os espetáculos em benefício tinham como alvo os retornos financeiros, os dois beneficiados provavelmente viram n'O demônio familiar algum potencial nesse sentido, quem sabe com base na reação das plateias na estreia. Se foi esse o caso, não estavam equivocados, pois, além dessas duas apresentaçóes, a peça teve mais quatro.

Além disso, desde que foi inaugurado, o Teatro D. Maria II mantinha uma indicação dos gêneros de espetáculos nele proibidos. Tal indicação pressupunha que, por ser subvencionado, esse teatro deveria influenciar os repertórios dos demais teatros. Ocorre, como já dito, que em 4 de outubro de 1860 foi baixado o Regulamento da Administração dos Teatros, que substituiu o de 1853, e nele o elenco dos gêneros dramáticos para o D. Maria II foi ampliado numa tentativa de fazer concorrência aos outros teatros e equilibrar as contas dessa sala, que se encontravam no vermelho. Com a entrada em vigor desse Regulamento, passou-se a encenar no D. Maria II todos os gêneros de comédia e drama, justamente o que se verifica nos espetáculos em que Judith e $O$ demônio familiar foram representados, e nos demais em que essa comédia fez parte da récita. Ou seja, naquele contexto apostar na encenaçáo de diferentes peças musicadas tornou-se uma questáo de sobrevivência para as companhias teatrais.

A julgar pelos termos desse decreto, ainda, somos levados a pensar que $O$ demônio familiar já fazia parte do repertório do D. Maria II, embora não tivesse sido encenado. Não foi possível saber como a comédia de Alencar chegou a Portugal. De concreto podemos afirmar que sua primeira edição foi feita em 1858, no Rio, alguns meses após a estreia no Teatro Ginásio, pela Tipografia Soares e Irmão, livreiros portugueses estabelecidos na cidade desde 1846, na Rua da Alfândega, 6. ${ }^{26}$ A segunda edição é de 1864, feita pela editora de Garnier, na França, e é um exemplar dessa tiragem que consta do acervo do teatro D. Maria II. Mas como a estreia em Lisboa ocorreu em 1860, o original utilizado pelo teatro ou correspondia a um exemplar da primeira edição, que pode ter chegado a Portugal na bagagem de algum ator e/ou empresário que esteve pelo Rio, tratando-se, portanto, de uma contrafação, ou foi fruto do trabalho de algum copista.

Quanto a ter sido trabalho de copista, também não conseguimos avançar com as fontes a que tivemos acesso. Tudo o que conseguimos apurar foi que os copistas estavam presentes na maior parte dos teatros portugueses da época, pelos quais eram contratados e recebiam ordenados mensais e que, tanto em Portugal quanto no Brasil, trabalhavam em casa e recebiam uma quantia por cada ato que copiavam (SOUSA BASTOS, 1908, p. 44). Mas havia

\footnotetext{
${ }^{26}$ Essa tipografia foi registrada em 1846 com o nome de Tipografia Comercial de Soares e Companhia, e em 1857 se transformou em Soares e Irmão. A partir de 1869 ela passou a pertencer a Nicolau Henrique Soares e, em 1872, desapareceu, só reabrindo em 1886 (BERGER, 1985, p. 54).
} 
copistas que realizavam essa atividade por conta própria e negociavam seu trabalho com empresários teatrais que sabiam ser reproduçôes ilegais. ${ }^{27}$

Se a peça encenada foi uma contrafação, estaríamos diante de um caso peculiar, pois as contrafaçôes de peças portuguesas no Brasil eram o mais comum, tanto que esse foi um problema que mobilizou a atenção de Almeida Garrett e Alexandre Herculano, que se empenharam em conseguir a aprovação de leis que garantissem aos autores portugueses os direitos e remuneraçóes pela publicação e encenação de suas obras no Brasil. Nos anos 1860 ainda se contava com a dramaturgia portuguesa ou com as traduçóes do francês realizadas por portugueses para alimentar o repertório teatral brasileiro e, para atender a essa demanda, as contrafaçóes se tornaram muito comuns. Da situação inversa, não se conhecem casos para o período analisado.

Voltamos aqui a um assunto deixado em suspensão páginas atrás, o de que tudo leva a crer que Alencar não teve notícias dessas encenaçôes. Em primeiro lugar, porque não existem informaçóes sobre contratos firmados entre ele e empresários portugueses, os quais, caso tivessem sido assinados, provavelmente teriam sido citados em textos que ele publicou em jornais ou na sua correspondência pessoal. Em segundo lugar, sabe-se dele também que não levava desaforos para casa e não fugia a uma polêmica, tanto que se envolveu em várias ao longo da sua vida, basta lembrarmos as travadas com Pinheiro Chagas em $1866^{28}$; com Nabuco em 1875 (COUTINHO, 1978); ou daquela em torno da adaptação para o teatro do seu $O$ guarani, em 1874 . Se ele tivesse tido notícias das representaçôes da sua comédia em Lisboa, insistimos, provavelmente teria se manifestado na imprensa, até porque sabia da impossibilidade de submeter os que cometiam tais delitos a penalidades, em função da inexistência de acordos entre Brasil e Portugal que garantissem ganhos para a nação de origem do autor com a encenação e circulação de obras teatrais (LAJOLO; ZILBERMAN, 2001, p. 63). A ex-colônia, como se sabe, recusou vários acordos com a ex-metrópole e apenas em 1888 foi assinada uma simples declaração conjunta em que os dois países concordavam "em que os autores de obras literárias e artísticas de cada um dos países gozassem no outro da mesma proteção legal [...] que os autores nacionais, com respeito à propriedade literária” (MAGALHÃES, 1999, p. 65). ${ }^{29}$

A polêmica com $O$ guarani pode ajudar a entender um pouco melhor a posição de Alencar em relação a tais temas. O episódio teve início quando o escritor acusou Visconti de Coaracy e Pereira da Silva de adaptarem seu romance para o teatro à sua revelia. Na ocasião,

\footnotetext{
${ }^{27}$ Em 1852, por exemplo, A Marmota Fluminense (RJ) publicou uma nota dizendo que Joaquim Manuel de Macedo teve sua comédia Fantasma branco, encenada pela Companhia do Teatro de Santa Isabel (Recife), sem sua autorizaçáo, o que o fez levar o caso aos tribunais. Germano de Oliveira, empresário desse teatro, procurou defender-se argumentando que comprara a cópia de alguém cujo nome não quis revelar. Ver $A$ Marmota Fluminense (RJ), n. 231, p. 1-2, 30 jan. 1852.

${ }^{28}$ Archivo Pittoresco (PT), ano 9, n. 31, p. 198, 1866. O artigo é de Pinheiro Chagas.

${ }^{29}$ Portugal já possuía uma legislação dessa natureza desde 1851.
} 
ele publicou uma matéria no Jornal do Commercio em que manifestou sua indisposição com os empresários que anunciavam peças sem licença dos autores, e com adaptadores que viviam ilicitamente "dos remendos de obras alheias remidos em farsas e chocanices", declarando que transferira aos tribunais competentes a decisão sobre o ocorrido. ${ }^{30}$ No ano seguinte, Alencar formulou e apresentou um projeto de lei que "visava reconhecer a propriedade literária como expressão do trabalho intelectual materializado no impresso" (GODOY, 2017, p. 574). Embora o projeto não tratasse diretamente da literatura dramática, nele Alencar legislou sobre diferentes modos de reproduçáo ilegal de obras, inclusive a reprodução pública por exibição ou representação. Do artigo 3 do seu projeto constava que a reprodução pública integral ou geral de obras "sendo feita por terceiro sem consentimento do autor, constituía crime de contrafação passível das mesmas penas dos crimes de furto (GODOY, 2017, p. 584).

Rodrigo Godoy argumentou convincentemente que a preocupação de Alencar com a representaçáo dos seus textos baseou-se na sua experiência pessoal com o drama $A s$ asas de um anjo, retirado de cartaz em 1858 pela polícia após a terceira representação. Na imprensa, o assunto ganhou projeçáo. No Correio Mercantil, Francisco Otaviano considerou injusta a proibição e afirmou não saber o que motivara a decisão da polícia (FARIA, 1989, p. 89); no Diário do Rio de Janeiro, José Carlos de Souza Ferreira declarou que a proibição náo se baseava em fatos justificáveis, uma vez que a peça só teria sido retirada de cena após três representaçóes e sem que as audiências tivessem manifestado qualquer reprovaçáo, ${ }^{31}$ e Quintino Bocaiúva argumentou tratar-se de um "absurdo, ilegal, atentatório das leis pátrias [...] um sequestro da inteligência não autorizado por disposição alguma e repelido pelo consenso unânime da consciência pública". ${ }^{32}$

Ao publicar As asas de um anjo, em 1860, Alencar incluiu uma advertência em que dizia que a peça, embora impressa, não podia ser representada sem sua licença (GODOY, 2017, p. 585). A primeira impressão de $O$ demônio familiar, que é de 1858, não trazia observação semelhante, o que nos leva a concordar com Godoy que, depois do ocorrido com As asas de um anjo, Alencar passou a olhar com mais atenção e a acompanhar de perto as impressóes e encenaçôes de suas obras, o que reforça nossa hipótese de que ele ignorou as encenaçóes do D. Maria II.

Por fim, gostaríamos de chamar atenção para mais um detalhe: é possível que pelo menos um brasileiro tenha tido notícias das representaçôes d'O demônio familiar em Lisboa ou até mesmo assistido a alguma delas, embora não tenha feito qualquer menção ao assunto. Referimo-nos ao ator e empresário João Caetano, que se encontrava naquela cidade desde o dia 17 de outubro de $1860 .{ }^{33}$

\footnotetext{
${ }^{30}$ Jornal do Commercio (RJ), ano 52, n. 107, p. 2, 19 abr. 1874.

${ }^{31}$ Diário do Rio de Janeiro (RJ), ano 38, n. 171, p. 1, 27 jun. 1858.

${ }^{32}$ Diário do Rio de Janeiro (RJ), ano 38, n. 172, p. 2, 28 jun. 1858.

${ }^{33}$ A Marmota (RJ), n. 1217, p. 2, 30 nov. 1860.
} 
Na sua ida à Europa, João Caetano conheceu o Conservatório de Paris e, quando passou por Lisboa, não apenas encenou $A$ dama de S. Tropez, no teatro D. Maria II, ${ }^{34}$ como assistiu a vários espetáculos teatrais neste e outros teatros, dentre eles a tragédia Judith, que ficou em cartaz de 1 a 30 de dezembro de 1860, sendo que $O$ demônio familiar fez parte das cinco primeiras récitas em que esse drama foi encenado. Consta que ele de tal forma se emocionou com a performance de Emília das Neves que por duas vezes se aproximou do proscênio e beijou suas mãos, e que ela lhe retribuiu "com um beijo na testa" (UM DOS SEUS ADMIRADORES, 1873, p. 218).

Em carta publicada no jornal fluminense $A$ Marmota do dia 30 de novembro de 1860, João Caetano afirmou que mantinha intenso contato com os atores dos elencos do D. Maria, do Ginásio e do Trindade em Lisboa. Se ele assistiu a alguma das encenaçóes de $O$ demônio familiar, não podemos afirmar, mas é muito provável que pelo menos tenha tomado conhecimento delas por meio dos atores com os quais convivia ou pelos anúncios dos jornais. Se este foi o caso, sua omissão sobre o assunto talvez estivesse relacionada aos problemas que ele e Alencar vivenciaram em 1860, em relação ao drama O jesuíta, que Joáo Caetano encomendara ao dramaturgo para ser representado no espetáculo do dia 7 de setembro de 1861, em comemoraçáo à independência. No final de 1860, de acordo com João Roberto Faria, Alencar já tinha em mãos o drama, do qual João Caetano não gostou e negou-se a encenar. $\mathrm{Na}$ ocasiâo, portanto, os dois estavam com as relaçôes estremecidas e talvez por esse motivo João Caetano tenha silenciado sobre a passagem de $O$ demônio familiar pelo palco português mais importante da época (FARIA, 2009, p. 59).

Do episódio que nos propusemos analisar, esses foram os resultados alcançados a partir da documentação que tínhamos em mãos. Ao chegarmos ao final deste exercício percebemos que ele redundou num texto que oferece menos certezas e respostas, e mais indicaçóes de caminhos e questôes para investigaçôes futuras. Sem dúvida documentos adicionais podem ser localizados em arquivos aos quais não tivemos acesso ou nos quais não nos ocorreu pesquisar, bem como outras pessoas poderáo levantar novas perguntas ou ver detalhes que nos passaram despercebidos.

Com base no que as fontes nos revelaram, porém, cremos pelo menos ser possível afirmar que a presença, circulação e adoção de textos teatrais brasileiros por companhias portuguesas no século XIX são um campo em aberto que pode revelar facetas ainda pouco conhecidas de um processo mais amplo de trocas e circulaçóes culturais, no qual tiveram papel de destaque mediadores tais como adaptadores, atores, ensaiadores e outros sujeitos ligados ao fazer teatral. Futuras pesquisas sobre o tema podem contribuir para que se tenha acesso a visóes alternativas sobre a presença do teatro brasileiro em palcos portugueses; as formas como a dramaturgia brasileira foi apropriada pela ex-metrópole e o possível local que lhe foi reservado nos seus palcos no Oitocentos.

\footnotetext{
${ }^{34}$ Revista Contemporânea de Portugal e do Brasil (PT), v. 2, p. 340, 1860.
} 


\section{Periódicos}

A Revolução de Setembro (PT), ano 21, n. 5.578, 4 dez. 1860.

A Revolução de Setembro (PT), ano 21, n. 5.589, 18 dez. 1860.

A Revolução de Setembro (PT), ano 21, n. 5.594, 23 dez. 1860.

A Revolução de Setembro (PT), ano 21, n. 5.595, 25 dez. 1860.

Archivo Pittoresco (PT), ano 9, n. 31, 1866.

$A$ Marmota (RJ), n. 898, 10 nov. 1857.

A Marmota (RJ), n. 1.217, 30 nov. 1860.

A Marmota Fluminense (RJ), n. 231, 30 jan. 1852.

Diário da Manhã (PT), n. 364, 20 set. 1876.

Diário do Brasil (RJ), ano 3, n. 164, 18 set. 1883.

Diário do Rio de Janeiro (RJ), ano 38, n. 171, 27 jun. 1858.

Diário do Rio de Janeiro (RJ), ano 38, n. 172, 28 jun. 1858.

Diário do Rio de Janeiro (RJ), ano 46, n. 56, 6 mar. 1866.

Gazetinha (RJ), ano 1, n. 144, 28 jun. 1882.

Jornal do Commercio (RJ), ano 52, n. 107, 19 abr. 1874.

O Occidente (PT), ano 29, n. 29, 20 out. 1906.

Pontos nos is (PT), 13 ago. 1886.

Revista Contemporânea de Portugal e do Brasil (PT), v. 2, 1860.

Revista Illustrada (RJ), ano 8, n. 3, 16 jun. 1883.

\section{Referências}

ABREU, Martha. Da senzala ao palco: canções escravas e racismo nas Américas (1870-1930). Campinas: UNICAMP, 2017.

ALENCAR, José de. $O$ demônio familiar. Rio de Janeiro: Tipografia Soares e Irmão, 1858.

ALONSO, Ângela. Flores, votos e balas: o movimento abolicionista brasileiro (1868-1888). São Paulo: Companhia das Letras, 2005.

AZEVEDO, Célia Maria Marinho de. Onda negra, medo branco: o negro no imaginário das elites do século XIX. São Paulo: Annablume, 2004.

BAILLIE, Marianne. Lisbon in the years 1821, 1822 and 1823. V. 2. London: John Murray, 1824. 
BALME, Christopher. Histórias globais do teatro: modernização, esferas públicas e redes teatrais. In: WERNECK, Maria Helena; REIS, Ângela de Castro (orgs.) Rotas de teatro: entre Portugal e Brasil. Rio de Janeiro: 7 Letras, 2016.

BERGER, Paulo. A tipografia no Rio de Janeiro. Impressores bibliográficos (1808-1900). Rio de Janeiro: Companhia Industrial de Papel Piraí, 1985.

BEZERRA, Valéria C. Entre o nacional e o estrangeiro: José de Alencar e a constituição da literatura brasileira em cenário internacional. Tese (Doutorado em Estudos da Linguagem) Instituto de Estudos da Linguagem, Universidade Estadual de Campinas, Campinas, 2016. BORGES, Valdeci. O "romance brasileiro" de José de Alencar nas páginas da imprensa fluminense de seu tempo. Anais do SILEL, Uberlândia, v. 3, n. 1, 2013.

CASTILHO, Antônio Feliciano de. Coroa poética no aniversário de suas majestades fidelíssimas o Sr. Rei D. Luiz e a Senhora Rainha D. Maria de Saboya. Lisboa: Sociedade Tipográfica Franco Portuguesa, 1862.

CHAGAS, Pinheiro. Anuário do Archivo Pittoresco. Lisboa, jan. 1866.

CHALHOUB, Sidney. Visóes da liberdade. Uma história das últimas décadas da escravidão na Corte. São Paulo: Companhia das Letras, 1990.

COLEÇÃO Oficial da Legislação Portuguesa. Lisboa: Imprensa Nacional, 1852.

COSTA, Maria Emília dos R. A vivência teatral entre 1771 e 1860. O que dizem as leis. Dissertação (Mestrado em Estudos de Teatro) - Faculdade de Letras, Universidade de Lisboa, Lisboa, 2014.

COUTINHO, Afrânio (org.). A polêmica Alencar-Nabuco. Rio de Janeiro/Brasília: Tempo Brasileiro/UNB, 1978.

CYMBRON, Luísa M. Francisco de Sá Noronha e L'Arco di Sant'Anna: para o estudo da ópera em Portugal (1860-1870). Trabalho apresentado para Prova de Habilitação. Faculdade de Ciências Sociais e Humanas, Universidade Nova de Lisboa. Lisboa, 1990.

CRUZ, Duarte Ivo. O teatro em português. Da expansão às independências. Revista Camóes, Lisboa, n. 19, 2006.

DAVIS, Natalie. Z. O retorno de Martin Guerre. Rio de Janeiro: Paz e Terra, 1987.

FARIA, João Roberto. José de Alencar e o teatro. São Paulo: EDUSP, 1989.

FARIA, João Roberto. Alencar dramaturgo. Uma apresentação. Revista de Letras, Fortaleza, v. 2, n. 29, jan./jul. 2009.

FARIA, João Roberto. José de Alencar e o demônio familiar. Campinas: UNICAMP, 2003.

FERREIRA, Licínia. Júlio César Machado cronista de teatro: os folhetins d'A Revolução de Setembro e do Diário de Notícias. Dissertação (Mestrado em Estudos de Teatro) - Faculdade de Letras, Universidade de Lisboa, Lisboa, 2011. 
FILIPE, Guilherme. Quando as revistas eram de ano. Sinais de Cena, Lisboa, v. 18, 2012. GODOY, Rodrigo Camargo de. José de Alencar e os embates em torno da Propriedade Literária no Rio de Janeiro (1856-1875). Estudos Históricos, Rio de Janeiro, v. 30, n. 62, set./dez. 2017.

GONÇALVES, Isabel Maria D. N. A música teatral na Lisboa de Oitocentos: uma abordagem através da obra de Joaquim Casimiro Júnior (1808-1892). Tese (Doutorado em Ciências Musicais) - Faculdade de Letras, Universidade de Lisboa, Lisboa, 2012.

GRANJA, Lúcia. Rio-Paris: primórdios da publicação da literatura brasileira chez Garnier. Revista Letras, Santa Maria, v. 23, n. 47, jul./dez. 2013.

HEINEBERG, Ilana. Um Brasil para francês ler: das traduçóes de $O$ guarany e Innocência ao exotismo dos romances de Adrien Delpech. In: ABREU, Márcia (org). Romances em movimento. A circulaçâo transatlântica dos impressos (1789-1914). Campinas: UNICAMP, 2016.

LAJOLO, Marisa; ZILBERMAN, Regina. O preço da leitura. Leis e números por detrás das letras. São Paulo: Ática, 2001.

MAGALHĀES, José Calvet de. Breve história das relaçōes diplomáticas entre Brasil e Portugal. São Paulo: Paz e Terra, 1999.

MARQUES, João Pedro. O retorno do escravismo em meados do século XIX. Análise Social, Lisboa, v. 41, n. 180, 2006.

MELO, Francisco Manuel de. Cartas de Amor e Cartas de Guia de Casados. Porto: Lello \& Irmão, [s.d.]

OLIVEIRA, Joaquim Augusto de. Revista de 1858. Lisboa. Tipografia de Joaquim Germano de Sousa Neves. 1859.

OUTEIRINHO, Maria de Fátima. Da crônica-folhetim no oitocentismo português: algumas (in)visibilidades. In: SILVA, Jorge Bastos; CASTANHEIRA, Maria Zulmira (orgs.) Entre Classicismo e Romantismo: ensaios de cultura e literatura. Porto: FLUP/CETAPS, 2013. PIMENTEL, Maria do Rosário Pimentel. Chão de sombras. Estudos sobre a escravatura. Lisboa: Colibri, 2010.

PRADO, Décio de Almeida. Os demônios familiares de Alencar. Revista do Instituto de Estudos Brasileiros. São Paulo, v. 15, 1974.

SANTOS, Carlos. Cinquenta anos de teatro. Memórias dum ator. Lisboa: Tipografia Empresa Nacional de Publicidade, 1950.

SOUSA BASTOS, Antônio de. Carteira do artista. Lisboa: Libânio da Silva, 1898.

SOUSA BASTOS, Antônio de. Dicionário do Teatro Português. Lisboa: Libânio da Silva, 1908.

SOUZA, Silvia Cristina Martins de. O palco como tribuna. Uma interpretação de $\mathrm{O}$ demônio familiar, de José de Alencar. Curitiba: Aos Quatro Ventos, 2003. 
UM DOS SEUS ADMIRADORES. Emília das Neves. Documentos para sua biografia. Lisboa: Livraria Universal Silva Júnior, 1873.

WERNECK, Maria Helena A solução dos transatlânticos. In: WERNECK, Maria Helena; REIS, Ângela de Castro (orgs). Rotas de teatro entre Portugal e Brasil. Rio de Janeiro: Sete Letras, 2016.

VAZ, Gil. Viagem à roda da Parvonia. Lisboa: Empresa Literária de Lisboa, [s.d.]

WIEBKE, Roben de A. Romance brasileiro em tradução alemã: O guarany e Innocência, produto nacional e best-seller no longo século XIX. In: ABREU, Márcia. (org). Romances em movimento. A circulação transatlântica dos impressos (1789-1914). Campinas: UNICAMP, 2016. 